\title{
Retraction
}

\section{Retracted: Increasing the Stimulation Dose of rFSH in Unexpected Poor Responders Is Not Associated with Better IVF Outcome}

\author{
The Scientific World Journal \\ Received 11 October 2012; Accepted 11 October 2012 \\ Copyright (C) 2012 The Scientific World Journal. This is an open access article distributed under the Creative Commons Attribution \\ License, which permits unrestricted use, distribution, and reproduction in any medium, provided the original work is properly \\ cited.
}

This article has been retracted as it was found to contain falsified data. Additionally, it was found that the same article was published in Ginekologia Polska (2012, 83, 2, 111-115) [1].

\section{References}

[1] L. Tutuncu and O. Dundar, "Increasing the stimulation dose of $\mathrm{rFSH}$ in unexpected poor responders is not associated with better IVF outcome," The Scientific World Journal, vol. 2012, Article ID 202804, 5 pages, 2012. 